\title{
Bill Hayton, The South China Sea: The Struggle for
} Power in Asia,

New Haven, London, Yale University Press, 2014, 298 pp.

\section{Sébastien Colin}

Translator. Peter Brown

\section{OpenEdition}

12 Journals

Electronic version

URL: http://journals.openedition.org/chinaperspectives/7061

DOI: 10.4000/chinaperspectives.7061

ISSN: 1996-4617

\section{Publisher}

Centre d'étude français sur la Chine contemporaine

\section{Printed version}

Date of publication: 1 September 2016

Number of pages: $71-72$

ISSN: 2070-3449

\section{Electronic reference}

Sébastien Colin, «Bill Hayton, The South China Sea: The Struggle for Power in Asia, », China Perspectives [Online], 2016/3 | 2016, Online since 01 September 2016, connection on 23 September 2020. URL : http://journals.openedition.org/chinaperspectives/7061; DOI : https://doi.org/10.4000/

chinaperspectives.7061 
access or control on the data generated by its official microblog account, which effectively prevents them from devising a better, more predictive egovernment strategy. This asymmetry of power over data in favour of corporations could, of course, be curbed by regulation.

The book also shows the variety and evolution of imaginaries and cybercultures across communities and time. There is a stark contrast between the optimism of the upper middle-class backpackers of 2006 described by Zhang, some of whom had taken to promoting long-term, gradual social change, and the disillusioned "losers" studied in 2012 by Szablewicz. The latter's ambivalent attitudes towards social norms and promises - rejecting and endorsing them at the same time - clearly show that they don't believe in the promises of modernisation anymore, nor do they believe in their capacity to change things, and instead turn to humour and self-mockery. This kind of fatalism answers, also, to Balla's conclusions that subjective motivations are better predictors of online participation than socio-economic factors, and more particularly by a perception that comments can actually bear fruit. The diaosi phenomenon described here may highlight the link between subjective motivations for (non)participation and socio-economic positions. Finally, as underlined by Yang, the book helps grasp the "subtleties of state power" (p. 4) and the "manifestations of the multiple ways of doing politics and being political" (p. 14). Lindtner draws on G. Barmé's concept of a "parasitic" (1) relationship to show how her respondents take advantage of the system, depend on it, and in many ways transform it. Thomas Chen proposes the term "alter-production" to show how literary production works around censorship constraints and generates many original literary forms. Szablewicz relies on R. Williams' "structures of feelings," (2) and on the literature on desire (V. Fong, ${ }^{(3)} \mathrm{L}$. Hoffman, ${ }^{(4)} \mathrm{A}$. Kipnis $\left.{ }^{(5)}\right)$, to explain the ambivalences and limited radical potential of the diaosi meme. This makes the title of the book, "China's contested Internet," a little misaligned with the content. Indeed, the term "contested" resonates with the title of the very famous book Access Contested, ${ }^{(6)}$ which in fact points at very different kinds of contention on the Internet, such as the emergence of concern over Internet governance.

Nevertheless, the chapters in this book are in general very well researched and well connected to theoretical literature in political science, anthropology, sociology, and cultural studies among others. They skilfully articulate online and offline contexts, with sources collected through a variety of methods ranging from participant observation to in-depth interviews, to surveys and qualitative and quantitative content analysis. They constitute an excellent introduction to the Chinese Internet itself, as well as to research methods and theories on the Chinese Internet, and may be of great interest in a teaching context.

I Séverine Arsène is a researcher at CEFC and chief editor of China Perspectives (sarsene@cefc.com.hk).

1. Geremie R. Barmé, In the Red: On Contemporary Chinese Culture, New York, Columbia University Press, 1999, p. xiv.

2. Raymond Williams, Marxism and Literature, New York, Oxford University Press, 1977, p. 132.

3. Vanessa Fong, Only Hope: Coming of Age under China's One-Child Policy, Stanford, Stanford University Press, 2004, p. 98.

4. Lisa M. Hoffman, Patriotic Professionalism in Urban China: Fostering Talent, Philadelphia, Temple University Press, 2010.

5. Andrew B. Kipnis, Governing Educational Desire: Culture, Politics, and Schooling in China, Chicago, University of Chicago Press, 2011.

6. Ronald Deibert, John Palfrey, Rafal Rohozinski, and Jonathan Zittrain (eds), Access Contested: Security, Identity and Resistance in Asian Cyberspace, Cambridge, MA, MIT Press, 2012.

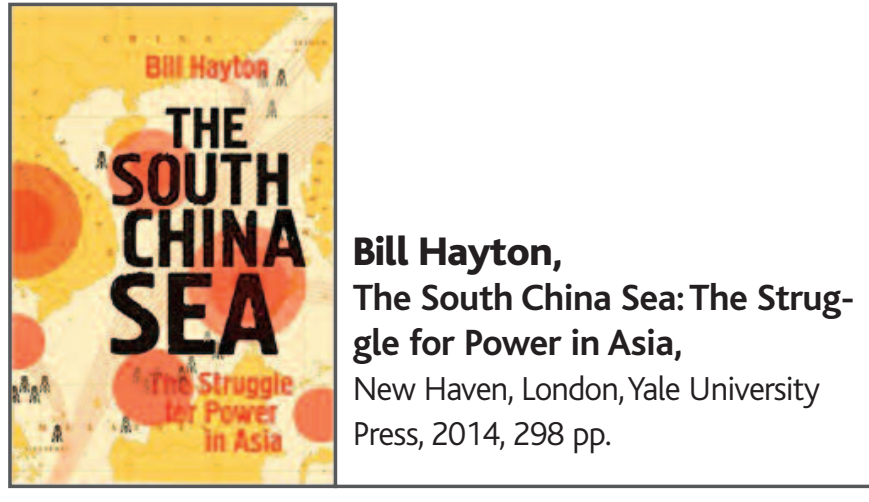

\section{SÉBASTIEN COLIN}

P ublished in 2014, Bill Hayton's work on the South China Sea stands out from much of the recent literature on this maritime space, on at least two counts. The first is that this is a single-author monograph, which deserves credit for providing a historical overview of the South China Sea from prehistoric times to the early 2010 s and for analysing the territorial disputes and power rivalries to which it has given rise. In doing so, the work calls upon a considerable body of academic literature, as well as interviews the author conducted with various actors, newspaper articles, and a number of reports and working papers. The book thus offers a broad synthesis that sets it apart from the numerous, albeit very interesting, collective works that have been published in recent years, many of which are the proceedings of conferences organised on a regular basis throughout the region. ${ }^{(1)}$ Whilst scholars working on the South China Sea will find in Hayton's book some worthwhile information and some useful and even highly valuable references, they will find little that is surprising in its overall approach. This is not a fundamental problem, however, as in my view this book is one of the first essential works for anyone (student, journalist, or diplomat) who wishes to gain insight, here quite comprehensive, into the hot spot that is the South China Sea today.

The second particular feature of The South China Sea lies in its largely journalistic style of writing. This is only natural, given that Hayton has been working for several years as a reporter for $B B C$ News. His style takes the form of long digressions on certain actors or personalities directly or indirectly involved in the dispute, or by descriptions of key episodes in what has been a troubled history, to say the least, of this maritime space. The various narrative devices employed by the author contribute to constructing a detailed history of actions undertaken by the different players: for example, the completion of China's annexation of the Paracel Islands in January 1974, something directly experienced by Gerald Kosh, an American soldier who was on a South-Vietnamese ship at the time (pp. 72-78), or the way in which the small American oil company Crestone managed to obtain an oil concession from China in waters claimed by Vietnam (pp. 123-127), or Cambodia's opposition to any mention of the question of the South China Sea in the joint communique issued at the meeting of ASEAN Foreign Ministers in Phnom Penh in 2012 (pp. 192-200). As a researcher with a careful eye for historical detail, I think these accounts have their own importance, although some descriptions, such as those concerning Wu Shicun, president of the China National Institute for South China Sea Studies (p. 248), do not

1. See, for example, Tran Truong Thuy and Le Thuy Trang (eds), Power, Law, and Maritime Order in the South China Sea, Lanham, Lexington Books, 2015, 378 pp. 
seem particularly useful. It is also regrettable that much of the information provided by the work is not systematically referenced, in spite of calling on an array of sources. Furthermore, the nine chapters would have doubtless benefited from the inclusion of subsections with inter-titles to enable a better exposition of the analysis. Lastly, whilst the geographer in me welcomes the four maps at the beginning of the work - a rare occurrence in Englishlanguage publishing, where cartography is often of poor quality if it exists at all - it is a pity that Hayton does not really refer to them, particularly Map 4, which in spite of its interest is not commented upon in the body of the work. A map of the oil concessions cited in Chapter 5 would have been particularly welcome.

The South China Sea is composed of an introduction, nine chapters, an epilogue and, following the endnotes, a few pages entitled "Acknowledgements and Further Reading," which underline the important number of people the author met or interviewed, as well as the reference works used or deemed useful for a greater understanding of the complex geo-history and geopolitics of the South China Sea.

The Introduction opens with an imagined standoff between China and the Philippines over the ownership of the Scarborough Shoal that degenerates into a situation of heightened military tension between China and the US. Through this ploy, Hayton reminds us at the outset that "the South China Sea is the first place where Chinese ambition has come face to face with American strategic resolve" (p. xvi), thus giving point to the work's subtitle, The Struggle for Power in Asia.

In the first three chapters Hayton goes over the long history of the South China Sea: "Wrecks and Wrongs: Prehistory to 1500" (pp. 1-28); "Maps and Lines: 1500 to 1948" (pp. 29-60); and "Danger and Mischief: 1946 to 1995" (pp. 61-89). His account is inevitably at odds with the official historiographies put forward by the various states to justify their sovereignty claims over the islands. In the process, the writer reminds us that these islands (which are actually various insular formations mostly composed of reefs, sand banks, and low-tide elevations) did not generate an enormous amount of interest before the European powers and Japan began to eye them for economic and strategic reasons from the late nineteenth century onward. Prior to the introduction of the Western colonial juggernauts, the South China Sea was a "Mediterranean" structured by trade and migration flows and circumscribed by state and territorial systems within which questions of sovereignty and borders particularly in Southeast Asia, dominated by the territorial system of the mandala - were posed differently.

The assertion by the Western powers and Japan putting their stamp on the South China Sea provoked a reaction in China in the final years of the Qing dynasty and then during the Republican period as shown by the organisation of naval expeditions, the production of geographical accounts, the creation of a Chinese toponymy for the islands, and lastly the drawing of maps, including that of the famous "U-shaped line," which would gradually lead to an official and national claim by China over the archipelagos of the South China Sea. The years 1946-47 were especially the time of French-Chinese rivalry before decolonisation, and the difficult construction of nation-states in the Philippines and Vietnam threw new players into the fray. There then followed unilateral appropriations in the Spratly archipelago, also motivated by a desire to exploit offshore hydrocarbon resources under a nascent United Nations Convention on the Law of the Sea. In short, there was a veritable "occupation race," which China was to join with some delay but not without force.
The following five chapters tackle in turn legal, economic, political (nationalisms), diplomatic, and military questions, while Chapter 9 ("Cooperation and its Opposites: Resolving the Disputes," pp. 239-265) considers the state of cooperation (or rather its absence) and the question of joint development, actively proposed by China in the zones subject to territorial claims by the other states, but in which none of the latter are interested insofar as that would amount to tacit recognition of China's right to these areas.

Chapter 4 ("Rocks and Other Hard Places: The South China Sea and International Law," Pp. 90-120) is noteworthy in that it presents the impossibility, as Hayton sees it, of settling sovereignty questions by reference to international law, and despite a number of reclamation and construction projects (some of which are described by the author) by the states concerned dating back to the early 1970s. Chapter 5 ("Something and Nothing: Oil and Gas in the South China Sea," pp. 121-150) confirms the myth of one archipelago, the Spratlys, overflowing with gas and oil reserves and clearly shows that the delimitation of oil exploration concessions is above all part of a political game aimed at affirming the sovereignty of one state at the expense of another. Chapter 6 ("Drums and Symbols: Nationalism," pp. 151-180) examines the place of nationalism in the disputes while also highlighting the complexity of relations between China and Vietnam and the respective place of China and the United States in the minds of Filipinos. Chapter 7 ("Ants and Elephants: Diplomacy," pp. 181-208) shows how the lack of interest by the United States in Southeast Asia (owing to the priority given to the war on terror by the Bush administration) gradually evolved, beginning in 2007-2008, into a new policy of the so-called "Pivot to Asia," the principal objective of which is to rebalance power relations with China, which had until then derived considerable benefit from American passivity. In this context, Southeast Asia has become a subject of competition between the two powers, making it very difficult to find a consensus within ASEAN on the question of the South China Sea. Chapter 8 ("Shaping the Battlefield: Military Matters," pp. 209-238) begins with the USNS Impeccable incident in 2009, which contributed to the increase in American concern over the question of access to the South China Sea, in spite of a continued significant imbalance in terms of military might.

Lastly, in the Epilogue (pp. 266-269), the work ends with the author's personal hope of one day seeing a delineated South China Sea, the main obstacle to which, according to Hayton, is China maintaining its "maximalist" (p. 267) claims through actors such as the People's Liberation Army, the China National Offshore Oil Corporation (CNOOC), and certain coastal provinces, and the permanence of the $U$-shaped line, which has become a "secular religion from primary school to the politburo" (p. 267). Without directly denying these points, I feel these final pages place too much emphasis on China's responsibility, and would have no doubt profited from a little more nuance given that the Philippines, Vietnam, Taiwan, and the United States, and before them France, Britain, and Japan, have also played a part in intensifying the complexity of an issue that entangles legal disputes over territorial sovereignty, great power rivalries, and the defence of economic interests.

\section{Translated by Peter Brown.}

I Sébastien Colin, associate professor at INALCO, Paris, has been on assignment at CEFC as researcher and deputy chief editor of China Perspectives since 1 September 2014 (sebastien.colin@cefc.com.hk). 